\title{
The Gut-Microbiota-Brain Axis in Autism Spectrum Disorder
}

\author{
Giselle C. Wong ${ }^{1,2} \bullet$ Johanna M. Montgomery ${ }^{2,3^{*}} \bullet$ Michael W. Taylor ${ }^{1,2 *}$ \\ ${ }^{1}$ School of Biological Sciences, University of Auckland, Auckland, New Zealand; \\ ${ }^{2}$ Centre for Brain Research, University of Auckland, Auckland, New Zealand; \\ ${ }^{3}$ Department of Physiology, University of Auckland, Auckland, New Zealand \\ *These authors contributed equally
}

Author for correspondence: Johanna Montgomery, Department of Physiology, University of Auckland, Auckland, New Zealand. Email: jm.montgomery@auckland.ac.nz

Doi: https://doi.org/10.36255/exonpublications.autismspectrumdisorders.2021.gutmicrobiota

\begin{abstract}
Autism spectrum disorder (ASD) is a neurodevelopmental disorder characterized by impairments in social interactions/behaviors and increased stereotypical repetitive behavior. Gastrointestinal disorders, ranging from severe constipation to diarrhea, are particularly prevalent for people on the autism spectrum, which may relate to an underlying dysbiosis (breakdown or imbalance) in the gut microbial community. Many studies have also identified changes in the gut microbiome in ASD compared to neurotypical cohorts in animal models and human populations. Microbial probiotics to help revert these gut microbial changes have been tested in animal models of ASD. Some have shown reversal of ASD behaviors and modulating the integrity of the gastrointestinal epithelial barrier. The gut-microbiota-brain axis has been described as a multidirectional communication channel between the three systems: the gut, gut microbes, and the brain, but whether these gastrointestinal microbes play a role in the context of ASD and whether they can be harnessed as a target for gastrointestinal therapies in humans is yet to be determined.
\end{abstract}

Keywords: autism spectrum disorder; animal model; gut microbiome; microbiota; zinc

In: Autism Spectrum Disorders. Grabrucker AM (Editor). Exon Publications, Brisbane, Australia. ISBN: 978-0-6450017-8-5; Doi: https://doi.org/10.36255/exonpublications. autismspectrumdisorders. 2021

Copyright: The Authors.

License: This open access article is licenced under Creative Commons Attribution-NonCommercial 4.0 International (CC BY-NC 4.0) https://creativecommons.org/licenses/by-nc/4.0/ 


\section{INTRODUCTION}

Autism spectrum disorder (ASD) is a neurodevelopmental condition that typically includes impairments in social communication/interaction and an increase in stereotyped, repetitive behavior, as defined by the DSM-5 Manual (1). Autism was first clinically described by Kanner in 1943, with the reported prevalence of the condition increasing in recent years from $~ 5$ in 10,000, in 1999, (2) to 1 in 54 in 2020 (3). The factors responsible for this apparent increase are unclear. However, it could be due in part to greater awareness of the condition as well as changes to the diagnostic criteria of ASD. ASD is more commonly diagnosed in males than females (3 males: 1 female) (4). While the characteristics described above are generally associated with ASD, it involves a highly heterogeneous phenotype that differs from person to person and ranges from so-called 'high-functioning' individuals of exceptionally high intellect to severely intellectually handicapped people requiring life-long care.

ASD commonly co-occurs with other conditions such as epilepsy, Down syndrome, and Fragile X syndrome, which may mask the presence of ASD due to their more prominent features (5). Based on twin studies, the concordance rate of ASD in monozygotic twins (who share all of their genes) is higher than in dizygotic twins (who share around half of their genes), indicating that there are strong genetic factors associated with ASD $(2,3)$. A wide range of genetic mutations has been identified in genome-wide association studies of ASD, but no single gene mutation has been linked to more than $1 \%$ of all ASD cases $(4,5)$. Of the vast array of genetic de novo mutations, copy number variations, and chromosomal rearrangements associated with ASD, many converge towards disrupted synapse pathways in the brain (6). For example, single protein mutations that affect any of the components involved in the neurexin-neuroligin-PSD-95-SAPAP-SHANK complex result in a similar mechanism of synaptic disruption in ASD (7).

This chapter introduces the potential role of gut microorganisms (the "gut microbiota") in ASD and discusses how these complex microbial communities may be manipulated as therapies for ASD-related challenges.

\section{ASD AND THE GUT}

The gut microbiota refers to the microorganisms (mainly bacteria and fungi) living in the gastrointestinal tract, while the microbiome describes both the organisms themselves and their collective genomic capabilities. The colonization of the gut by microbes may begin before birth, although this remains controversial $(8,9)$. The microbiome dynamically fluctuates as diet and environmental exposure change throughout development (10). Bacterial cells were once thought to outnumber human cells by 10: 1 (11), though recent estimates suggest that this ratio is closer to 1.3: 1 (12). Gut commensals are essential for aiding digestion of food (13), providing resistance against pathogens (14), and stimulating the host (human) immune system (15). Although the bacterial biota of the human gastrointestinal tract is quite conserved at the broad phylum level, where members of the Bacteroidetes and Firmicutes typically dominate $(13,16)$, the composition of bacterial species varies widely among individuals (17). Despite this variation in 
bacterial composition, the functional capabilities of the gut microbiota are highly conserved among individuals, suggesting the presence of a 'core microbiome' of microbial genes (18).

Due to difficulties with sampling the gut tissue itself (e.g., via colonoscopy), many studies use fecal samples as a non-invasive proxy for the gut microbiota. Although the fecal microbiota appears to be highly representative of the colonic microbiota, it is a less useful proxy for other parts of the gastrointestinal tract $(19,20)$. In practice, fecal matter includes a subset of both mucosa- and lumeninhabiting microorganisms, and sampling of feces remains the method of choice for most human gut microbiome studies. Next-generation sequencing technologies have provided a highly efficient, culture-independent approach to study gut microbiota, whereby the 16 S ribosomal RNA gene is specifically amplified by PCR for taxonomic classification due to the universal presence of this gene in bacteria and archaea.

Children with ASD commonly have a more limited food repertoire and increased refusal to eat certain foods compared with neurotypical children. This could be due to hyper/hyposensitivity to sensory inputs associated with ASD $(21,22)$. Diet plays a large role in determining gut microbial composition and function $(23,24)$; thus, a selective diet could affect the gut microbial community. Some parents of children with ASD suspect that food allergies and sensitivity to dietary gluten and casein result in gastrointestinal problems and therefore implement gluten-free, casein-free (GF/CF) diets (25). However, despite the selective eating habits and specialized diets of some individuals on the autism spectrum, such as a GF/CF diet, there is no evidence of differential energy intake and growth compared to neurotypical children $(26,27)$. A small number of studies have found changes in ASD-related behaviors following implementation of a GF/CF diet (28), but many other studies have identified no such changes $(25,29)$. Overall, the effect of a GF/CF diet on ASD behaviors remains inconclusive.

The reported prevalence of gastrointestinal (GI) disorders (ranging from severe constipation to diarrhea in individuals with ASD varies widely, with estimates ranging from $2.2 \%$ to $96.8 \%$ of the ASD population $(30,31)$. Despite this considerable heterogeneity, overall, most studies suggest a greater prevalence of GI problems in children with ASD compared with their neurotypical counterparts $(32,33)$. Behavioral changes combined with communication difficulties often make it hard for clinicians to detect underlying gastrointestinal problems in individuals with ASD (34), contributing to the variable findings of gut problems in this population. A compromised intestinal barrier (so-called "leaky gut") describes GI problems associated with the permeability and integrity of the gut epithelial barrier (35-37), which may contribute to ASD. In this situation, dietary products and/or bacterial metabolites can pass through this barrier and enter the bloodstream, where immune responses and interactions and other effects on the central nervous system/brain may occur.

\section{ASD AND THE GUT-MICROBIOTA-BRAIN AXIS}

The gut-microbiota-brain axis refers to the bidirectional communication between gut microbes and the brain (38-40). Changes in the gut microbiome have been 
described in children with ASD (41-43), though this relationship varies considerably among studies, and differences reduce somewhat once ASD, and control cohorts are carefully matched (44). If changes in the gut microbiome do occur, this may also alter the synthesis of microbial products. Gut microbial metabolites include short-chain fatty acids, as well as vitamins essential for human health $(24,45,46)$. Other microbial products include compounds that act as neurotransmitters that may influence synapse function and communication with the brain $(47,48)$. For example, gastrointestinal disorders and changes in the gut microbiota are known to affect serotonin signaling in the gut and the brain $(49,50)$. Serotonin and other microbial metabolites, such as gamma-aminobutyric acid (GABA), can act as neurotransmitters, whereby the vagus nerve presents a direct pathway for communication between the brain and gut (51) (Figure 1).

By inducing stress in mice, researchers have been able to measure changes in the gut microbiota (52), demonstrating how the brain can affect the gut in ways that could potentially lead to disruption of the gut barrier (53) and inflammation from gut immune responses (54). In germ-free mice that are not exposed to any bacterial sources and are kept under strictly sterile conditions, anxiety-related behaviors are common, as well as deficiencies in gut physiology and immune development $(55,56)$. Specific pathogen-free mice harbor gut bacteria but are

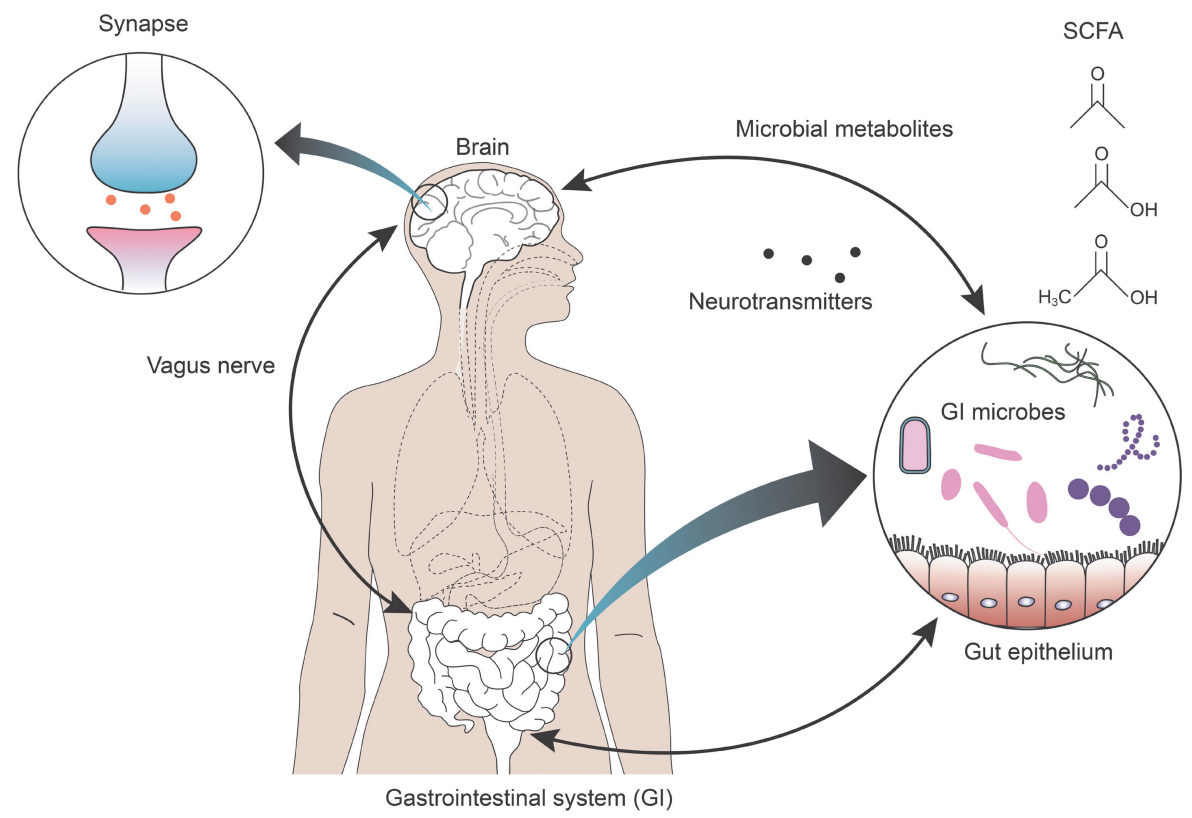

Figure 1. The bidirectional communication pathways between the gastrointestinal system, gut microbes, and the brain. Direct stimulation between the gastrointestinal system and the brain occurs via the vagus nerve and metabolites from gastrointestinal microbes such as shortchain fatty acids (SCFA), as well as neurotransmitters that can communicate with the brain via the blood. 
free from a list of specific pathogens. Compared to germ-free mice with no gut microbes, these mice exhibit profound differences in behavior and brain chemical signaling $(57,58)$, suggesting the importance of gut microbe interactions.

\section{GUT MICROBIAL THERAPIES}

The gut microbiota offers a therapeutic target due to their manipulable nature. There exist several avenues by which the microbiota can potentially be altered, and we discuss these in the context of ASD research below.

\section{Probiotics}

Probiotics consist of live microbes that are used to benefit host health by supplementing 'healthy' gut microbiota (59). Better-known types include bacteria such as various species of Lactobacillus and Bifidobacterium, which are readily available in fermented products as well as in powder or capsule form. Probiotics have been used to treat a wide variety of conditions in humans, such as antibiotic-associated diarrhea $(60,61)$ and irritable bowel disease $(62-64)$. There is much anecdotal evidence that probiotic consumption has helped individuals with ASD, both in terms of improving gut problems (such as diarrhea or constipation) and improving some ASD-related behaviors. The use of probiotic treatments for ASDassociated behavioral characteristics has also been supported in mouse models of $\operatorname{ASD}(65,66)$, while trials in humans with $\operatorname{ASD}(60,67)$ have sometimes been equivocal due to limitations such as small numbers of participants or lack of a placebo group. A 2020 review of probiotic supplementation for individuals with ASD concluded that the efficacy of probiotics looks promising, but there is still a need for standardized clinical trials to assess the effects of probiotic supplementation in individuals with ASD (67).

\section{Diet alterations}

It is well established that changes in diet have the potential to alter the composition of the human gut microbiota. For example, in a landmark 2014 paper, David and colleagues demonstrated significant and reproducible changes to the gut microbiota within 1-2 days of transitioning to a heavily animal protein-based diet (68). Similarly, marked differences in gut microbiota composition can be seen between members of more traditional, hunter-gatherer societies compared with urban dwellers consuming more of a contemporary, Western-type diet (69). Microbial diversity tends to be richer in the former group, likely reflecting a lesser reliance on antimicrobial products as well as consumption of a greater breadth of seasonal foods (69).

People on the autism spectrum typically have a more selective food repertoire, which can result in lower nutritional intake, ultimately leading to the development of deficiencies in fiber, calcium, and protein uptake $(70,71)$. Selective eating habits may involve food refusal and high-frequency selective food intake or even gluten-free/casein-free/lactose-free parental restriction of diets, often making it difficult to provide a balanced diet to children with ASD, especially those with 
sensory sensitivities $(72,73)$. Many studies only focus on children with ASD and their eating behaviors, with a need for longitudinal studies focusing on dietary deficiencies and their association with selective food intake.

There is also increasing interest in the use of prebiotics, so-called functional foods that are not broken down by host enzymes but are instead fermented by gut microbes, in turn stimulating their growth and activity $(74,75)$. Prebiotics such as partially hydrolyzed guar gum (76), galactooligosaccharide (77), and bovine colostrum product (78) have contributed to a reduction in gastrointestinal symptoms: mainly abdominal pain and increased bowel movement along with changes in the membership of the gut microbiota. Suggestions to combine prebiotics with probiotics or exclusion diets (e.g., GF/CF diet) to improve efficacy have the potential to have long-term effects but to date have been demonstrated with limited effectiveness, partially due to the vast differences in treatment duration, dosage, and regimens (79).

\section{Antibiotics}

Antibiotic usage has substantially increased in the past few decades (80), accompanied by a concomitant increase in antibiotic-resistant infections $(80,81)$. While antibiotics can be exceptionally effective against various diseases of bacterial origin, the widespread non-targeted use of antibiotics calls for stricter guidelines on antibiotic stewardship (82). Narrow-spectrum antibiotics or even vaccines targeting specific pathogens in the gut (83) could be used to improve gut health and cure infections (84). Doing so may open up an ecological niche in the gut following the eradication of specific microbes, therefore pro- or prebiotics may be beneficial to fill this gap with commensal beneficial microbes $(85,86)$.

A small oral vancomycin treatment study resulting in short-term beneficial changes in ASD behaviors was one of the first few papers to suggest a link between the gut-microbiota-brain axis and ASD (87). The authors suggested that the vancomycin antibiotic treatment may temporarily deter colonization of potentially pathogenic bacteria in the gut, hinting at the promise of gastrointestinal therapies to ameliorate ASD symptoms.

\section{Fecal microbiota transplants}

Fecal transplants, whereby the gut microbes from a healthy donor(s) are introduced into the gut of an affected individual, have received considerable recent attention. To date, they are most notable for their success in treating persistent Clostridioides difficile-associated diarrhea $(88,89)$, with a highly impressive $>90 \%$ rate for curing recalcitrant infections (90). This approach has now been refined to reduce the risk of conferring infection and disease and improve patient palatability (91). Careful consideration of the fecal donor sample is crucial as various unwanted effects such as new-onset obesity may occur after fecal transplant therapy (92). Currently, the euphemistically termed "microbiota transfer therapy" has been proposed for a variety of human conditions, such as obesity (93), ulcerative colitis (94), and ASD (95). However, to date, the efficacy of this approach has only been unequivocally proven for $C$. difficile infections. 
Microbiota transfer therapy has shown promise to shift gut microbial composition in individuals with ASD towards neurotypical gut profiles (95). Importantly, these changes were accompanied by improvements in GI symptoms and behaviors associated with ASD, at least for eight weeks following a 10-week treatment period. Although promising, these results need to be viewed cautiously: this was an open-label study where placebo effects could not be assessed. Moreover, confounding effects such as antibiotic treatment to suppress pathogenic bacteria, and acid-pump inhibition medication to reduce stomach acidity and improve the survival rate of the transferred microbes, could also have impacted the observed effects (95). Encouragingly, however, Kang et al. subsequently reported sustained ASD behavior and GI symptom improvements for at least two years post-microbiota transfer therapy (96).

\section{ANIMAL MODELS OF ASD}

Although ASD is only known to affect humans, there are many different animal models of ASD. The use of such models can enable a better understanding of the potential causes and mechanisms underlying ASD, which could ultimately result in the development of treatments for those that require them. Existing animal models of ASD include nematodes (Caenorhabditis elegans (97)), monkeys (Macaca sp. (98)), rats (Rattus norvegicus (99)), and the widely used mice (Mus musculus (100)). While using animals that are most similar to humans, such as monkeys, would be logical, this brings wider complications of financial burden, long developmental periods, and ethical concerns.

ASD is generally diagnosed in a clinical setting, whereas autism-like behaviors in animals are assayed through a series of behavioral tests. To determine if the animal model accurately reflects the human disorder, determining construct, face, and predictive validity is important (101). Construct validity refers to how well the causative mechanism of the disorder in the animal model represents the human condition; this can be difficult to achieve for ASD models as there is no single mutation that represents all ASD cases. Therefore, there is an intention to mimic environmental and/or genetic aspects of ASD in humans in various ASD animal models. Face validity is the extent to which the animal model phenotype represents the human disorder on a behavioral and cellular level. Behavioral tests are well established in mouse models of ASD (102). However, ASD behaviors such as deficits in social-emotional reciprocity and non-verbal communicative behaviors are challenging to model in mice. Predictive validity relates to how well the treatments for reversing or preventing some of the symptoms of the human disorder are reflected in the animal model. Currently, there are no reliable "treatments" for ASD, making it difficult to achieve predictive validity in animal models of ASD.

Mouse models of ASD can be created using varying approaches. For example, the maternal immune activation (MIA) mouse model is created by infecting a pregnant mouse with either live viruses or immunogenic substances (e.g., the bacterial endotoxin Lipopolysaccharide or the synthetic double-stranded RNA analogue polyinosinic-polycytidilic acid) to stimulate an immune reaction, resulting in offspring that display ASD-like behaviors, as well as autism-related cellular 
pathological changes (103). This model is based on data for humans that have correlated viral infection in the first trimester of pregnancy with a significantly increased likelihood of the offspring developing ASD (104). Administering valproic acid in utero is another method used to create an ASD mouse model that exhibits ASD-associated lesions in the motor nuclei of the brain (105). Buffington et al. (66) identified a specific bacterium (Lactobacillus reuteri) as being absent from mice in the maternal high-fat diet (MHFD) mouse model of autism spectrum disorder. After introducing L. reuteri into the MHFD mice, the social behavior deficits were restored with further effects on synapses and oxytocin levels in the brain, providing further evidence of a brain-gut connection (66) (Figure 2).

Inoculation of the probiotic bacterium Bacteroides fragilis in the MIA mouse model (Figure 2) led to a reversal of some ASD-like behaviors, restored blood serum bacterial metabolite levels, and improved gut epithelial barrier function (65) (Figure 2). This study illustrated a possible mechanism of ASD, as well as suggesting a potential therapy. However, translating results from animal models into humans requires caution. In animal models of other disorders, such as schizophrenia, the treatments seem promising, but the same beneficial effects are not always observed when treating humans (106). However, by using animal models of ASD, one can have more control over environmental variables, which are valuable for understanding this complex disorder.

Genomic animal models are developed using ASD-related genetic mutations/ variants detected in humans (107), which generally also display face and construct validity. Although these models do not embody all aspects of ASD, they do encapsulate certain features of ASD that are useful to study. Animal models are invaluable for understanding the histopathological and pathophysiological mechanisms of ASD in the brain, as well as for testing treatments that may aid people carrying the same genetic/histopathological changes as the animal model.

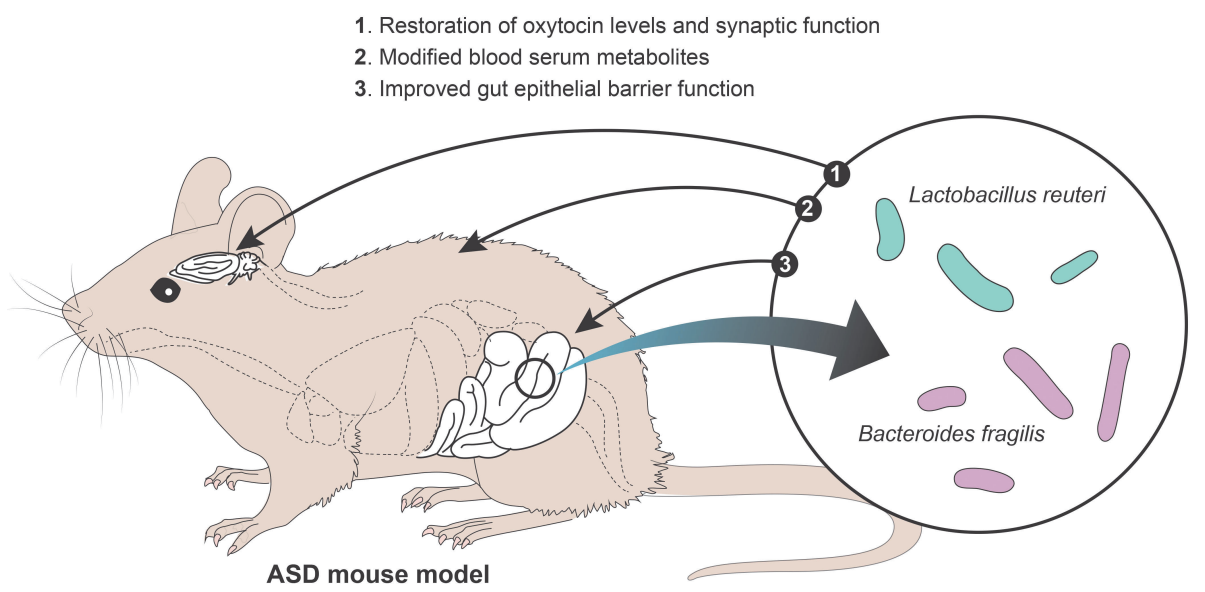

Figure 2. The effects of microbial-based therapies on mouse models of ASD $(65,66)$. Introduction of bacteria such as Lactobacillus reuteri and Bacteroides fragilis in mouse models of ASD have been shown to restore oxytocin levels and synaptic function in the brain, modify and restore blood serum metabolites and improve the gut epithelial barrier function. 
The marked heterogeneity of ASD genetics makes it hard to model the exact deletions, frameshift mutations, or translocation mutations in different individuals with ASD. The SHANK family of synaptic proteins (SHANK1-3) is highly linked to ASD, with point, deletion, and frameshift mutations observed in people affected by ASD. In mice, the Shank3 gene is found on chromosome 15qE3 (108), and many Shank3 mutant mouse lines with different Shank3 gene mutations have been created (109-114). A major ASD-Shank3 mouse model that has been widely utilized in ASD research is the Shank3B-/- ex13-16 mouse model, in which exons 13-16 of the Shank3B $\mathrm{B}^{-/}$gene are deleted (7); this maintains the overall effect of knocking out the gene, resulting in SHANK3 protein loss of function as seen in human ASD cases as well as Phelan-McDermid Syndrome. Most Shank3 mouse model studies use homozygous Shank3 mutant mice, whereas heterozygous Shank3 mutations are also found in individuals with ASD. The Shank3B ${ }^{-/-}$mutant mouse model (ex13-16) displays ASD-like behaviors, including repetitive behaviors (grooming) and deficits in social interaction (7). In addition to this, the loss of several proteins in the post-synaptic structure is observed in the mouse model, which is also seen in individuals with ASD (7). These behavioral and cellular mechanisms observed in these mice reflect those that occur in people with ASD, supporting the face validity of the Shank3B $B^{-1-}$ (ex13-16) mouse model. In relation to the gut-brain axis, differences in Shank3 mouse gut microbiota compared to wild-type mice have been observed, and subsequent Lactobacillus reuteri probiotic treatment was beneficial towards ASD behaviors; this provides further evidence that the gut-microbiota-brain axis in ASD can be manipulated (115). Overall, the use of ASD mouse models is crucial towards understanding how microbes can affect a neurodevelopmental condition (ASD) and how we can target this towards treatments for gastrointestinal disorders and behaviors associated with ASD.

\section{DIETARY ZINC AND THE GASTROINTESTINAL TRACT IN ASD}

Zinc is a key micronutrient required for many processes in the body, including enzyme functionality (116), immune system functioning (117), hormone production (118), DNA repair (119), and protection against oxidative stress (120). Dietary zinc is absorbed mainly in the small intestine, where intestinal mucosa metallothionein proteins, ZIP proteins, and zinc transporters control zinc homeostasis (121-123). Zinc deficiency is widespread in individuals with ASD and is also seen with attention deficit hyperactivity disorder (ADHD) and depression (124). Zinc deficiency can impair gastrointestinal function, conceivably resulting in further deficiencies of other micronutrients (125). ADHD and depression cooccur in some individuals with ASD, but while the role of zinc in the pathology of these conditions is unknown, zinc treatment has been trialed for these conditions $(126,127)$. Some of the gastrointestinal problems reported in ASD reflect increases in intestinal permeability $(128,129)$. This could affect the absorption of zinc, which primarily occurs in the gut, leading to the zinc deficiencies that have been described in individuals with ASD (130). On the other hand, zinc deficiencies from the diet could also affect the integrity of the intestinal epithelial membrane as zinc is required as a cofactor/catalyst for many membrane transporters and structural membrane proteins $(131,132)$. 
Chronic zinc deficiency can affect the diversity, composition, and functional capacity of the gut microbiota (133), but to date, such analyses with the gut microbiota of humans or mice with ASD have not been undertaken. Short-chain fatty acids produced by gut microbes may contribute to lowering intestinal $\mathrm{pH}$, in turn increasing zinc solubility and thus allowing increased dietary zinc absorption (134-136). Additionally, the gut microbiota may change the availability of zinc, which is required for many membrane transport systems essential for known pathogens such as Campylobacter jejuni (137). As a result, zinc can become a limiting factor, leading to competition for this micronutrient among microbes. On the other hand, excess dietary zinc may negatively affect the gut microbiota, as the host immune system uses zinc to protect against pathogens (138). Thus, regulation of zinc homeostasis is important for both the health of the host and the gut microbiota.

The human immune system requires zinc to provide an innate and adaptive humoral response towards pathogens (139). Perturbations of the immune system can occur in ASD (140-142), but whether zinc plays a role in mediating this is unknown. Complex pathways connecting the central nervous system (CNS) and the immune system are essential, especially during the early stages of neurodevelopment (143). The findings of an altered immune system in some individuals with ASD (141, 144-146), together with the presence of a bidirectional immune system-CNS system, contribute to another model of ASD pathogenesis in which autoimmune reactivity could play a role.

Nutrient acquisition from the diet is partially compromised in zinc deficiency due to a reduction of functional zinc metalloenzymes and disaccharidases for digestion (147). Diarrhea and malnutrition can result from zinc deficiencies as the integrity and permeability of the gut epithelial barrier require zinc to maintain its function (148). These alterations make the gut more susceptible to pathogen establishment and growth, which can further reshape gut microbiota composition.

Some of the genes implicated in ASD interact with zinc: in particular, zinc interacts with the SHANK3 protein, the master regulator of synapses, to provide the essential post-synaptic density scaffolding network required for synaptic transmission in the brain (149). The SAM domain of SHANK3 proteins contains a zinc-binding site that requires zinc to create the scaffolding structure at the postsynaptic density (150). Zinc deficiency and the loss-of-function Shank gene mutations have implications for assembly, maintenance and neurotransmission function at the synapse, leading to loss of synaptic control mechanisms (151). Zinc uptake transporters (ZIP4 and ZIP2) co-localize with SHANK3 proteins at the plasma membrane: in Shank3 $\alpha \beta$ knockout mice and Shank3 knockdown human cell lines, there is reduced co-localization of zinc uptake transporters (ZIP4 in particular) and SHANK3 proteins at the membrane (152).

Brain electrophysiology studies have shown that zinc is responsible for stabilizing the SHANK3 post-synaptic density by supporting the association between several SHANK3 proteins (153). Arons and colleagues (149) found that zinc is important in regulating SHANK3 activation in the brain, as SHANK3 proteins are central to regulating synaptic transmission via a zinc-sensitive signaling system. Disruption of this zinc-sensitive signaling system has been observed in Shank3 mutations related to ASD, which may have impacted the functionality and plasticity of synapses in the brain, possibly resulting in ASD behaviors $(149,154)$. 
Increasing dietary zinc in Shank3 mouse models of ASD reverses ASD-related behaviors in young mice and offspring of mice fed a zinc-supplemented diet $(155,156)$. Whether these dietary zinc effects partially or fully stem from changes in the gut, including gut permeability or the gut microbiome, is of significant interest.

\section{CONCLUSION}

There is increasing evidence for the gut-microbiota-brain axis and how the modulation of these systems may play a role in gastrointestinal health and modification of ASD-related behaviors. While many individuals on the autism spectrum may present with different gastrointestinal microbial communities from neurotypical people and experience gut disorders, the currently available treatments are limited. Supplemented dietary zinc treatment has shown potential in an ASD-mouse model with supported plasticity changes in the brain. Fecal microbial transfer therapy also shows promise towards changing the gut microbial community and has positively sustained long-term effects towards gastrointestinal issues in ASD. Understanding how these potential treatments involve the gut-microbiota-brain axis and what we can use to harness it with reproducibility in the future effectively is key.

Acknowledgment: The authors' ASD-related research has been supported by funding from the Marsden Fund (13-UOA-053), the Health Research Council of New Zealand (17/052), and the Minds for Minds Charitable Trust. The authors thank Vivian Ward for co-creating Figures 1 and 2 in this chapter.

Conflict of interest: The authors declare no potential conflict of interest with respect to research, authorship and/or publication of this chapter.

Copyright and permission statement: The authors confirm that the materials included in this chapter do not violate copyright laws. Where relevant, appropriate permissions have been obtained from the original copyright holder(s), and all original sources have been appropriately acknowledged or referenced.

\section{REFERENCES}

1. Association AP. American Psychiatric Association: Diagnostic and Statistical Manual of Mental Disorders: Diagnostic and Statistical Manual of Mental Disorders, Fifth Edition. Arlington, VA. 2013. https://doi.org/10.1176/appi.books.9780890425596

2. Folstein S, Rutter M. Infantile autism: a genetic study of 21 twin pairs. J Child Psychol Psychiatry. 1977;18(4):297-321. https://doi.org/10.1111/j.1469-7610.1977.tb00443.x

3. Castelbaum L, Sylvester CM, Zhang Y, Yu Q, Constantino JN. On the Nature of Monozygotic Twin Concordance and Discordance for Autistic Trait Severity: A Quantitative Analysis. Behav Genet. 2020;50(4):263-72. https://doi.org/10.1007/s10519-019-09987-2

4. Yoo H. Genetics of Autism Spectrum Disorder: Current Status and Possible Clinical Applications. Exp Neurobiol. 2015;24(4):257-72. https://doi.org/10.5607/en.2015.24.4.257 
5. El-Fishawy P, State MW. The genetics of autism: key issues, recent findings, and clinical implications. Psychiatr Clin North Am. 2010;33(1):83-105. https://doi.org/10.1016/j.psc.2009.12.002

6. Toro R, Konyukh M, Delorme R, Leblond C, Chaste P, Fauchereau F, et al. Key role for gene dosage and synaptic homeostasis in autism spectrum disorders. Trends Genet. 2010;26(8):363-72. https:// doi.org/10.1016/j.tig.2010.05.007

7. Peca J, Feliciano C, Ting JT, Wang W, Wells MF, Venkatraman TN, et al. Shank3 mutant mice display autistic-like behaviours and striatal dysfunction. Nature. 2011;472(7344):437-42. https://doi. org/10.1038/nature09965

8. Kennedy KM, Gerlach MJ, Adam T, Heimesaat MM, Rossi L, Surette MG, et al. Fetal meconium does not have a detectable microbiota before birth. Nat Microbiol. 2021. https://doi. org/10.1101/2021.02.17.431710

9. Walker RW, Clemente JC, Peter I, Loos RJF. The prenatal gut microbiome: are we colonized with bacteria in utero? Pediatr Obes. 2017;12 Suppl 1:3-17. https://doi.org/10.1111/ijpo.12217

10. Zmora N, Suez J, Elinav E. You are what you eat: diet, health and the gut microbiota. Nat Rev Gastroenterol Hepatol. 2019;16(1):35-56. https://doi.org/10.1038/s41575-018-0061-2

11. Luckey TD. Introduction to intestinal microecology. Am J Clin Nutr. 1972;25(12):1292-4. https:// doi.org/10.1093/ajcn/25.12.1292

12. Sender R, Fuchs S, Milo R. Are We Really Vastly Outnumbered? Revisiting the Ratio of Bacterial to Host Cells in Humans. Cell. 2016;164(3):337-40. https://doi.org/10.1016/j.cell.2016.01.013

13. Ley RE, Turnbaugh PJ, Klein S, Gordon JI. Microbial ecology: human gut microbes associated with obesity. Nature. 2006;444(7122):1022-3. https://doi.org/10.1038/4441022a

14. Stecher B, Hardt WD. Mechanisms controlling pathogen colonization of the gut. Curr Opin Microbiol. 2011;14(1):82-91. https://doi.org/10.1016/j.mib.2010.10.003

15. Cheng HY, Ning MX, Chen DK, Ma WT. Interactions Between the Gut Microbiota and the Host Innate Immune Response Against Pathogens. Front Immunol. 2019;10:607. https://doi. org/10.3389/fimmu.2019.00607

16. Arumugam M, Raes J, Pelletier E, Le Paslier D, Yamada T, Mende DR, et al. Enterotypes of the human gut microbiome. Nature. 2011;473(7346):174-80. https://doi.org/10.1038/nature09944

17. Human Microbiome Project C. Structure, function and diversity of the healthy human microbiome. Nature. 2012;486(7402):207-14. https://doi.org/10.1038/naturel1234

18. Turnbaugh PJ, Hamady M, Yatsunenko T, Cantarel BL, Duncan A, Ley RE, et al. A core gut microbiome in obese and lean twins. Nature. 2009;457(7228):480-4. https://doi.org/10.1038/nature07540

19. Tang Q, Jin G, Wang G, Liu T, Liu X, Wang B, et al. Current Sampling Methods for Gut Microbiota: A Call for More Precise Devices. Front Cell Infect Microbiol. 2020;10:151. https://doi.org/10.3389/ fcimb.2020.00151

20. Yasuda K, Oh K, Ren B, Tickle TL, Franzosa EA, Wachtman LM, et al. Biogeography of the intestinal mucosal and lumenal microbiome in the rhesus macaque. Cell Host Microbe. 2015;17(3):385-91. https://doi.org/10.1016/j.chom.2015.01.015

21. Marco EJ, Hinkley LB, Hill SS, Nagarajan SS. Sensory processing in autism: a review of neurophysiologic findings. Pediatr Res. 2011;69(5 Pt 2):48R-54R. https://doi.org/10.1203/PDR.0b013e3182130c54

22. Chistol LT, Bandini LG, Must A, Phillips S, Cermak SA, Curtin C. Sensory Sensitivity and Food Selectivity in Children with Autism Spectrum Disorder. J Autism Dev Disord. 2018;48(2):583-91. https://doi.org/10.1007/s10803-017-3340-9

23. Valdes AM, Walter J, Segal E, Spector TD. Role of the gut microbiota in nutrition and health. BMJ. 2018;361:k2179. https://doi.org/10.1136/bmj.k2179

24. Nicholson JK, Holmes E, Kinross J, Burcelin R, Gibson G, Jia W, et al. Host-gut microbiota metabolic interactions. Science. 2012;336(6086):1262-7. https://doi.org/10.1126/science.1223813

25. Keller A, Rimestad ML, Friis Rohde J, Holm Petersen B, Bruun Korfitsen C, Tarp S, et al. The Effect of a Combined Gluten- and Casein-Free Diet on Children and Adolescents with Autism Spectrum Disorders: A Systematic Review and Meta-Analysis. Nutrients. 2021;13(2). https://doi.org/10.3390/ nul3020470

26. Emond A, Emmett P, Steer C, Golding J. Feeding symptoms, dietary patterns, and growth in young children with autism spectrum disorders. Pediatrics. 2010;126(2):e337-42. https://doi.org/10.1542 /peds.2009-2391 
27. Graf-Myles J, Farmer C, Thurm A, Royster C, Kahn P, Soskey L, et al. Dietary adequacy of children with autism compared with controls and the impact of restricted diet. J Dev Behav Pediatr. 2013;34(7):449-59. https://doi.org/10.1097/DBP.0b013e3182a00d17

28. Whiteley P, Shattock P, Knivsberg AM, Seim A, Reichelt KL, Todd L, et al. Gluten- and casein-free dietary intervention for autism spectrum conditions. Front Hum Neurosci. 2012;6:344. https://doi. org/10.3389/fnhum.2012.00344

29. Hyman SL, Stewart PA, Foley J, Cain U, Peck R, Morris DD, et al. The Gluten-Free/Casein-Free Diet: A Double-Blind Challenge Trial in Children with Autism. J Autism Dev Disord. 2016;46(1):205-20. https://doi.org/10.1007/s10803-015-2564-9

30. Holingue C, Newill C, Lee LC, Pasricha PJ, Daniele Fallin M. Gastrointestinal symptoms in autism spectrum disorder: A review of the literature on ascertainment and prevalence. Autism Res. 2018;11(1):24-36. https://doi.org/10.1002/aur.1854

31. Ferguson BJ, Dovgan K, Takahashi N, Beversdorf DQ. The Relationship Among Gastrointestinal Symptoms, Problem Behaviors, and Internalizing Symptoms in Children and Adolescents With Autism Spectrum Disorder. Front Psychiatry. 2019;10:194. https://doi.org/10.3389/fpsyt.2019.00194

32. Lefter R, Ciobica A, Timofte D, Stanciu C, Trifan A. A Descriptive Review on the Prevalence of Gastrointestinal Disturbances and Their Multiple Associations in Autism Spectrum Disorder. Medicina (Kaunas). 2019;56(1). https://doi.org/10.3390/medicina56010011

33. McElhanon BO, McCracken C, Karpen S, Sharp WG. Gastrointestinal symptoms in autism spectrum disorder: a meta-analysis. Pediatrics. 2014;133(5):872-83. https://doi.org/10.1542/peds.2013-3995

34. Buie T, Campbell DB, Fuchs GJ, 3rd, Furuta GT, Levy J, Vandewater J, et al. Evaluation, diagnosis, and treatment of gastrointestinal disorders in individuals with ASDs: a consensus report. Pediatrics. 2010;125 Suppl 1:S1-18. https://doi.org/10.1542/peds.2009-1878C

35. Kelly JR, Kennedy PJ, Cryan JF, Dinan TG, Clarke G, Hyland NP. Breaking down the barriers: the gut microbiome, intestinal permeability and stress-related psychiatric disorders. Front Cell Neurosci. 2015;9:392. https://doi.org/10.3389/fncel.2015.00392

36. D’Eufemia P, Celli M, Finocchiaro R, Pacifico L, Viozzi L, Zaccagnini M, et al. Abnormal intestinal permeability in children with autism. Acta Paediatr. 1996;85(9):1076-9. https://doi. org/10.1111/j.1651-2227.1996.tb14220.x

37. de Magistris L, Familiari V, Pascotto A, Sapone A, Frolli A, Iardino P, et al. Alterations of the intestinal barrier in patients with autism spectrum disorders and in their first-degree relatives. J Pediatr Gastroenterol Nutr. 2010;51(4):418-24. https://doi.org/10.1097/MPG.0b013e3181dcc4a5

38. Martin CR, Osadchiy V, Kalani A, Mayer EA. The Brain-Gut-Microbiome Axis. Cell Mol Gastroenterol Hepatol. 2018;6(2):133-48. https://doi.org/10.1016/j.jcmgh.2018.04.003

39. Maiuolo J, Gliozzi M, Musolino V, Carresi C, Scarano F, Nucera S, et al. The Contribution of Gut Microbiota-Brain Axis in the Development of Brain Disorders. Front Neurosci. 2021;15:616883. https://doi.org/10.3389/fnins.2021.616883

40. Cryan JF, O'Riordan KJ, Cowan CSM, Sandhu KV, Bastiaanssen TFS, Boehme M, et al. The MicrobiotaGut-Brain Axis. Physiol Rev. 2019;99(4):1877-2013. https://doi.org/10.1152/physrev.00018.2018

41. Kang DW, Park JG, Ilhan ZE, Wallstrom G, Labaer J, Adams JB, et al. Reduced incidence of Prevotella and other fermenters in intestinal microflora of autistic children. PLoS One. 2013;8(7):e68322. https://doi.org/10.1371/journal.pone.0068322

42. Finegold SM, Dowd SE, Gontcharova V, Liu C, Henley KE, Wolcott RD, et al. Pyrosequencing study of fecal microflora of autistic and control children. Anaerobe. 2010;16(4):444-53. https://doi. org/10.1016/j.anaerobe.2010.06.008

43. Strati F, Cavalieri D, Albanese D, De Felice C, Donati C, Hayek J, et al. New evidences on the altered gut microbiota in autism spectrum disorders. Microbiome. 2017;5(1):24. https://doi. org/10.1186/s40168-017-0242-1

44. Vujkovic-Cvijin I, Sklar J, Jiang L, Natarajan L, Knight R, Belkaid Y. Host variables confound gut microbiota studies of human disease. Nature. 2020;587(7834):448-54. https://doi. org/10.1038/s41586-020-2881-9

45. Hill MJ. Intestinal flora and endogenous vitamin synthesis. Eur J Cancer Prev. 1997;6 Suppl 1:S43-5. https://doi.org/10.1097/00008469-199703001-00009 
46. Magnusdottir S, Ravcheev D, de Crecy-Lagard V, Thiele I. Systematic genome assessment of B-vitamin biosynthesis suggests co-operation among gut microbes. Front Genet. 2015;6:148. https://doi. org/10.3389/fgene.2015.00148

47. Huang F, Wu X. Brain Neurotransmitter Modulation by Gut Microbiota in Anxiety and Depression. Front Cell Dev Biol. 2021;9:649103. https://doi.org/10.3389/fcell.2021.649103

48. Ma Q, Xing C, Long W, Wang HY, Liu Q, Wang RF. Impact of microbiota on central nervous system and neurological diseases: the gut-brain axis. J Neuroinflammation. 2019;16(1):53. https://doi. org/10.1186/s12974-019-1434-3

49. Yano JM, Yu K, Donaldson GP, Shastri GG, Ann P, Ma L, et al. Indigenous bacteria from the gut microbiota regulate host serotonin biosynthesis. Cell. 2015;161(2):264-76. https://doi.org/10.1016/j. cell.2015.02.047

50. Yaghoubfar R, Behrouzi A, Ashrafian F, Shahryari A, Moradi HR, Choopani S, et al. Modulation of serotonin signaling/metabolism by Akkermansia muciniphila and its extracellular vesicles through the gut-brain axis in mice. Sci Rep. 2020;10(1):22119. https://doi.org/10.1038/s41598-020-79171-8

51. Breit S, Kupferberg A, Rogler G, Hasler G. Vagus Nerve as Modulator of the Brain-Gut Axis in Psychiatric and Inflammatory Disorders. Front Psychiatry. 2018;9:44. https://doi.org/10.3389/ fpsyt.2018.00044

52. Karl JP, Hatch AM, Arcidiacono SM, Pearce SC, Pantoja-Feliciano IG, Doherty LA, et al. Effects of Psychological, Environmental and Physical Stressors on the Gut Microbiota. Front Microbiol. 2018;9:2013. https://doi.org/10.3389/fmicb.2018.02013

53. Zheng G, Victor Fon G, Meixner W, Creekmore A, Zong Y, M KD, et al. Chronic stress and intestinal barrier dysfunction: Glucocorticoid receptor and transcription repressor HES1 regulate tight junction protein Claudin-1 promoter. Sci Rep. 2017;7(1):4502. https://doi.org/10.1038/s41598-017-04755-w

54. Gao X, Cao Q, Cheng Y, Zhao D, Wang Z, Yang H, et al. Chronic stress promotes colitis by disturbing the gut microbiota and triggering immune system response. Proc Natl Acad Sci U S A. 2018;115(13):E2960-E9. https://doi.org/10.1073/pnas.1720696115

55. Peirce JM, Alvina K. The role of inflammation and the gut microbiome in depression and anxiety. J Neurosci Res. 2019;97(10):1223-41. https://doi.org/10.1002/jnr.24476

56. Grover M, Kashyap PC. Germ-free mice as a model to study effect of gut microbiota on host physiology. Neurogastroenterol Motil. 2014;26(6):745-8. https://doi.org/10.1111/nmo.12366

57. Neufeld KM, Kang N, Bienenstock J, Foster JA. Reduced anxiety-like behavior and central neurochemical change in germ-free mice. Neurogastroenterol Motil. 2011;23(3):255-64, el19. https://doi. org/10.1111/j.1365-2982.2010.01620.x

58. Sudo N, Chida Y, Aiba Y, Sonoda J, Oyama N, Yu XN, et al. Postnatal microbial colonization programs the hypothalamic-pituitary-adrenal system for stress response in mice. J Physiol. 2004;558(Pt 1):263-75. https://doi.org/10.1113/jphysiol.2004.063388

59. Fuller R. Probiotics in man and animals. J Appl Bacteriol. 1989;66(5):365-78. https://doi. org/10.1111/j.1365-2672.1989.tb05105.x

60. Blaabjerg S, Artzi DM, Aabenhus R. Probiotics for the Prevention of Antibiotic-Associated Diarrhea in Outpatients-A Systematic Review and Meta-Analysis. Antibiotics (Basel). 2017;6(4). https://doi. org/10.3390/antibiotics6040021

61. Guo Q, Goldenberg JZ, Humphrey C, El Dib R, Johnston BC. Probiotics for the prevention of pediatric antibiotic-associated diarrhea. Cochrane Database Syst Rev. 2019;4:CD004827. https://doi. org/10.1002/14651858.CD004827.pub5

62. Ganji-Arjenaki M, Rafieian-Kopaei M. Probiotics are a good choice in remission of inflammatory bowel diseases: A meta analysis and systematic review. J Cell Physiol. 2018;233(3):2091-103. https:// doi.org/10.1002/jcp.25911

63. Yang M, Yu Y, Lei PG, Yuan J. Comparative efficacy and safety of probiotics for the treatment of irritable bowel syndrome: a systematic review and network meta-analysis protocol. BMJ Open. 2019;9(12):e027376. https://doi.org/10.1136/bmjopen-2018-027376

64. Dale HF, Rasmussen SH, Asiller OO, Lied GA. Probiotics in Irritable Bowel Syndrome: An Up-to-Date Systematic Review. Nutrients. 2019;11(9). https://doi.org/10.3390/nul1092048 
65. Hsiao EY, McBride SW, Hsien S, Sharon G, Hyde ER, McCue T, et al. Microbiota modulate behavioral and physiological abnormalities associated with neurodevelopmental disorders. Cell. 2013;155(7):1451-63. https://doi.org/10.1016/j.cell.2013.11.024

66. Buffington SA, Di Prisco GV, Auchtung TA, Ajami NJ, Petrosino JF, Costa-Mattioli M. Microbial Reconstitution Reverses Maternal Diet-Induced Social and Synaptic Deficits in Offspring. Cell. 2016;165(7):1762-75. https://doi.org/10.1016/j.cell.2016.06.001

67. Abdellatif B, McVeigh C, Bendriss G, Chaari A. The Promising Role of Probiotics in Managing the Altered Gut in Autism Spectrum Disorders. Int J Mol Sci. 2020;21(11). https://doi.org/ 10.3390/ijms21114159

68. David LA, Maurice CF, Carmody RN, Gootenberg DB, Button JE, Wolfe BE, et al. Diet rapidly and reproducibly alters the human gut microbiome. Nature. 2014;505(7484):559-63. https://doi. org/10.1038/nature 12820

69. Schnorr SL, Candela M, Rampelli S, Centanni M, Consolandi C, Basaglia G, et al. Gut microbiome of the Hadza hunter-gatherers. Nat Commun. 2014;5:3654. https://doi.org/10.1038/ncomms4654

70. Sharp WG, Berry RC, McCracken C, Nuhu NN, Marvel E, Saulnier CA, et al. Feeding problems and nutrient intake in children with autism spectrum disorders: a meta-analysis and comprehensive review of the literature. J Autism Dev Disord. 2013;43(9):2159-73. https://doi.org/10.1007/ s10803-013-1771-5

71. Herndon AC, DiGuiseppi C, Johnson SL, Leiferman J, Reynolds A. Does nutritional intake differ between children with autism spectrum disorders and children with typical development? J Autism Dev Disord. 2009;39(2):212-22. https://doi.org/10.1007/s10803-008-0606-2

72. Bandini LG, Curtin C, Phillips S, Anderson SE, Maslin M, Must A. Changes in Food Selectivity in Children with Autism Spectrum Disorder. J Autism Dev Disord. 2017;47(2):439-46. https://doi. org/10.1007/s10803-016-2963-6

73. Bandini LG, Anderson SE, Curtin C, Cermak S, Evans EW, Scampini R, et al. Food selectivity in children with autism spectrum disorders and typically developing children. J Pediatr. 2010;157(2):259-64. https://doi.org/10.1016/j.jpeds.2010.02.013

74. Gibson GR, Roberfroid MB. Dietary modulation of the human colonic microbiota: introducing the concept of prebiotics. J Nutr. 1995;125(6):1401-12. https://doi.org/10.1093/jn/125.6.1401

75. Roberfroid M. Prebiotics: the concept revisited. J Nutr. 2007;137(3 Suppl 2):830S-7S. https://doi. org/10.1093/jn/137.3.830S

76. Inoue R, Sakaue Y, Kawada Y, Tamaki R, Yasukawa Z, Ozeki M, et al. Dietary supplementation with partially hydrolyzed guar gum helps improve constipation and gut dysbiosis symptoms and behavioral irritability in children with autism spectrum disorder. J Clin Biochem Nutr. 2019;64(3):217-23. https://doi.org/10.3164/jcbn.18-105

77. Grimaldi R, Gibson GR, Vulevic J, Giallourou N, Castro-Mejia JL, Hansen LH, et al. A prebiotic intervention study in children with autism spectrum disorders (ASDs). Microbiome. 2018;6(1):133. https://doi.org/10.1186/s40168-018-0523-3

78. Sanctuary MR, Kain JN, Chen SY, Kalanetra K, Lemay DG, Rose DR, et al. Pilot study of probiotic/ colostrum supplementation on gut function in children with autism and gastrointestinal symptoms. PLoS One. 2019;14(1):e0210064. https://doi.org/10.1371/journal.pone.0210064

79. Ng QX, Loke W, Venkatanarayanan N, Lim DY, Soh AYS, Yeo WS. A Systematic Review of the Role of Prebiotics and Probiotics in Autism Spectrum Disorders. Medicina (Kaunas). 2019;55(5). https://doi. org/10.3390/medicina55050129

80. Van Boeckel TP, Gandra S, Ashok A, Caudron Q, Grenfell BT, Levin SA, et al. Global antibiotic consumption 2000 to 2010: an analysis of national pharmaceutical sales data. Lancet Infect Dis. 2014;14(8):742-50. https://doi.org/10.1016/S1473-3099(14)70780-7

81. Ventola CL. The antibiotic resistance crisis: part 1: causes and threats. P T. 2015;40(4):277-83.

82. Doron S, Davidson LE. Antimicrobial stewardship. Mayo Clin Proc. 2011;86(11):1113-23. https:// doi.org/10.4065/mcp.2011.0358

83. Monira S, Shabnam SA, Ali SI, Sadique A, Johura FT, Rahman KZ, et al. Multi-drug resistant pathogenic bacteria in the gut of young children in Bangladesh. Gut Pathog. 2017;9:19. https://doi. org/10.1186/s13099-017-0170-4 
84. Kamada N, Seo SU, Chen GY, Nunez G. Role of the gut microbiota in immunity and inflammatory disease. Nat Rev Immunol. 2013;13(5):321-35. https://doi.org/10.1038/nri3430

85. Haque SZ, Haque M. The ecological community of commensal, symbiotic, and pathogenic gastrointestinal microorganisms - an appraisal. Clin Exp Gastroenterol. 2017;10:91-103. https://doi. org/10.2147/CEG.S126243

86. Cunningham M, Azcarate-Peril MA, Barnard A, Benoit V, Grimaldi R, Guyonnet D, et al. Shaping the Future of Probiotics and Prebiotics. Trends Microbiol. 2021. https://doi.org/10.1016/j. tim.2021.01.003

87. Sandler RH, Finegold SM, Bolte ER, Buchanan CP, Maxwell AP, Vaisanen ML, et al. Short-term benefit from oral vancomycin treatment of regressive-onset autism. J Child Neurol. 2000;15(7):429-35. https://doi.org/10.1177/088307380001500701

88. Bakken JS, Borody T, Brandt LJ, Brill JV, Demarco DC, Franzos MA, et al. Treating Clostridium difficile infection with fecal microbiota transplantation. Clin Gastroenterol Hepatol. 2011;9(12):1044-9. https://doi.org/10.1016/j.cgh.2011.08.014

89. Rohlke F, Stollman N. Fecal microbiota transplantation in relapsing Clostridium difficile infection. Therap Adv Gastroenterol. 2012;5(6):403-20. https://doi.org/10.1177/1756283X12453637

90. Brandt LJ, Aroniadis OC, Mellow M, Kanatzar A, Kelly C, Park T, et al. Long-term follow-up of colonoscopic fecal microbiota transplant for recurrent Clostridium difficile infection. Am J Gastroenterol. 2012;107(7):1079-87. https://doi.org/10.1038/ajg.2012.60

91. Petrof EO, Gloor GB, Vanner SJ, Weese SJ, Carter D, Daigneault MC, et al. Stool substitute transplant therapy for the eradication of Clostridium difficile infection: 'RePOOPulating' the gut. Microbiome. 2013;1(1):3. https://doi.org/10.1186/2049-2618-1-3

92. Alang N, Kelly CR. Weight gain after fecal microbiota transplantation. Open Forum Infect Dis. 2015;2(1):ofv004. https://doi.org/10.1093/ofid/ofv004

93. Marotz CA, Zarrinpar A. Treating Obesity and Metabolic Syndrome with Fecal Microbiota Transplantation. Yale J Biol Med. 2016;89(3):383-8.

94. Angelberger S, Reinisch W, Makristathis A, Lichtenberger C, Dejaco C, Papay P, et al. Temporal bacterial community dynamics vary among ulcerative colitis patients after fecal microbiota transplantation. Am J Gastroenterol. 2013;108(10):1620-30. https://doi.org/10.1038/ajg.2013.257

95. Kang DW, Adams JB, Gregory AC, Borody T, Chittick L, Fasano A, et al. Microbiota Transfer Therapy alters gut ecosystem and improves gastrointestinal and autism symptoms: an open-label study. Microbiome. 2017;5(1):10. https://doi.org/10.1186/s40168-016-0225-7

96. Kang DW, Adams JB, Coleman DM, Pollard EL, Maldonado J, McDonough-Means S, et al. Longterm benefit of Microbiota Transfer Therapy on autism symptoms and gut microbiota. Sci Rep. 2019;9(1):5821. https://doi.org/10.1038/s41598-019-42183-0

97. Schmeisser K, Parker JA. Worms on the spectrum - C. elegans models in autism research. Experimental Neurology. 2018;299:199-206. https://doi.org/10.1016/j.expneurol.2017.04.007

98. Zhao H, Jiang YH, Zhang YQ. Modeling autism in non-human primates: Opportunities and challenges. Autism Res. 2018;11(5):686-94. https://doi.org/10.1002/aur.1945

99. Pensado-López A, Veiga-Rúa S, Carracedo Á, Allegue C, Sánchez L. Experimental Models to Study Autism Spectrum Disorders: hiPSCs, Rodents and Zebrafish. Genes. 2020;11(11). https://doi. org/10.3390/genes11111376

100. Kazdoba TM, Leach PT, Yang M, Silverman JL, Solomon M, Crawley JN. Translational Mouse Models of Autism: Advancing Toward Pharmacological Therapeutics. Curr Top Behav Neurosci. 2016;28:1-52. https://doi.org/10.1007/7854_2015_5003

101. Chadman KK, Yang M, Crawley JN. Criteria for validating mouse models of psychiatric diseases. Am J Med Genet B Neuropsychiatr Genet. 2009;150B(1):1-11. https://doi.org/10.1002/ajmg.b.30777

102. Silverman JL, Yang M, Lord C, Crawley JN. Behavioural phenotyping assays for mouse models of autism. Nat Rev Neurosci. 2010;11(7):490-502. https://doi.org/10.1038/nrn2851

103. Malkova NV, Yu CZ, Hsiao EY, Moore MJ, Patterson PH. Maternal immune activation yields offspring displaying mouse versions of the three core symptoms of autism. Brain Behav Immun. 2012;26(4):607-16. https://doi.org/10.1016/j.bbi.2012.01.011 
104. Atladottir HO, Pedersen MG, Thorsen P, Mortensen PB, Deleuran B, Eaton WW, et al. Association of family history of autoimmune diseases and autism spectrum disorders. Pediatrics. 2009;124(2):687-94. https://doi.org/10.1542/peds.2008-2445

105. Rodier PM. Animal model of autism based on developmental data. Mental Retardation and Developmental Disabilities Research Reviews. 1996;2(4):249-56. https://doi.org/10.1002/ (SICI)1098-2779(1996)2:4<249::AID-MRDD9>3.0.CO;2-L

106. Jones RN, Manly J, Glymour MM, Rentz DM, Jefferson AL, Stern Y. Conceptual and measurement challenges in research on cognitive reserve. J Int Neuropsychol Soc. 2011;17(4):593-601. https://doi. org/10.1017/S1355617710001748

107. Schroeder JC, Reim D, Boeckers TM, Schmeisser MJ. Genetic Animal Models for Autism Spectrum Disorder. In: Wöhr M, Krach S, editors. Social Behavior from Rodents to Humans: Neural Foundations and Clinical Implications. Cham: Springer International Publishing; 2017. p. 311-24. https://doi. org/10.1007/7854_2015_407

108. Durand CM, Betancur C, Boeckers TM, Bockmann J, Chaste P, Fauchereau F, et al. Mutations in the gene encoding the synaptic scaffolding protein SHANK3 are associated with autism spectrum disorders. Nat Genet. 2007;39(1):25-7. https://doi.org/10.1038/ng1933

109. Bozdagi O, Sakurai T, Papapetrou D, Wang X, Dickstein DL, Takahashi N, et al. Haploinsufficiency of the autism-associated Shank3 gene leads to deficits in synaptic function, social interaction, and social communication. Mol Autism. 2010;1(1):15. https://doi.org/10.1186/2040-2392-1-15

110. Jiang YH, Ehlers MD. Modeling autism by SHANK gene mutations in mice. Neuron. 2013;78(1): 8-27. https://doi.org/10.1016/j.neuron.2013.03.016

111. Mei Y, Monteiro P, Zhou Y, Kim JA, Gao X, Fu Z, et al. Adult restoration of Shank3 expression rescues selective autistic-like phenotypes. Nature. 2016;530(7591):481-4. https://doi.org/10.1038/ nature 16971

112. Zhou Y, Kaiser T, Monteiro P, Zhang X, Van der Goes MS, Wang D, et al. Mice with Shank3 Mutations Associated with ASD and Schizophrenia Display Both Shared and Distinct Defects. Neuron. 2016;89(1):147-62. https://doi.org/10.1016/j.neuron.2015.11.023

113. Jaramillo TC, Speed HE, Xuan Z, Reimers JM, Escamilla CO, Weaver TP, et al. Novel Shank3 mutant exhibits behaviors with face validity for autism and altered striatal and hippocampal function. Autism Res. 2017;10(1):42-65. https://doi.org/10.1002/aur.1664

114. Drapeau E, Riad M, Kajiwara Y, Buxbaum JD. Behavioral Phenotyping of an Improved Mouse Model of Phelan-McDermid Syndrome with a Complete Deletion of the Shank3 Gene. eNeuro. 2018;5(3). https://doi.org/10.1523/ENEURO.0046-18.2018

115. Tabouy L, Getselter D, Ziv O, Karpuj M, Tabouy T, Lukic I, et al. Dysbiosis of microbiome and probiotic treatment in a genetic model of autism spectrum disorders. Brain Behav Immun. 2018;73:310-9. https://doi.org/10.1016/j.bbi.2018.05.015

116. McCall KA, Huang C, Fierke CA. Function and mechanism of zinc metalloenzymes. J Nutr. 2000;130(5S Suppl):1437S-46S. https://doi.org/10.1093/jn/130.5.1437S

117. Prasad AS. Zinc in human health: effect of zinc on immune cells. Mol Med. 2008;14(5-6):353-7. https://doi.org/10.2119/2008-00033.Prasad

118. Ertek S, Cicero AF, Caglar O, Erdogan G. Relationship between serum zinc levels, thyroid hormones and thyroid volume following successful iodine supplementation. Hormones (Athens). 2010;9(3):263-8. https://doi.org/10.14310/horm.2002.1276

119. Song Y, Leonard SW, Traber MG, Ho E. Zinc deficiency affects DNA damage, oxidative stress, antioxidant defenses, and DNA repair in rats. J Nutr. 2009;139(9):1626-31. https://doi.org/10.3945/ jn.109.106369

120. Marreiro DD, Cruz KJ, Morais JB, Beserra JB, Severo JS, de Oliveira AR. Zinc and Oxidative Stress: Current Mechanisms. Antioxidants (Basel). 2017;6(2). https://doi.org/10.3390/antiox6020024

121. Maret W. The function of zinc metallothionein: a link between cellular zinc and redox state. J Nutr. 2000;130(5S Suppl):1455S-8S. https://doi.org/10.1093/jn/130.5.1455S

122. Liuzzi JP, Cousins RJ. Mammalian zinc transporters. Annu Rev Nutr. 2004;24:151-72. https://doi. org/10.1146/annurev.nutr.24.012003.132402 
123. Weaver BP, Dufner-Beattie J, Kambe T, Andrews GK. Novel zinc-responsive post-transcriptional mechanisms reciprocally regulate expression of the mouse Slc39a4 and Slc39a5 zinc transporters (Zip4 and Zip5). Biol Chem. 2007;388(12):1301-12. https://doi.org/10.1515/BC.2007.149

124. Grabrucker AM, Rowan M, Garner CC. Brain-Delivery of Zinc-Ions as Potential Treatment for Neurological Diseases: Mini Review. Drug Deliv Lett. 2011;1(1):13-23. https://doi. org/10.2174/2210304x11101010013

125. Roohani N, Hurrell R, Kelishadi R, Schulin R. Zinc and its importance for human health: An integrative review. J Res Med Sci. 2013;18(2):144-57.

126. Ghanizadeh A, Berk M. Zinc for treating of children and adolescents with attention-deficit hyperactivity disorder: a systematic review of randomized controlled clinical trials. Eur J Clin Nutr. 2013;67(1):122-4. https://doi.org/10.1038/ejcn.2012.177

127. Petrilli MA, Kranz TM, Kleinhaus K, Joe P, Getz M, Johnson P, et al. The Emerging Role for Zinc in Depression and Psychosis. Front Pharmacol. 2017;8:414. https://doi.org/10.3389/fphar.2017.00414

128. Ibrahim SH, Voigt RG, Katusic SK, Weaver AL, Barbaresi WJ. Incidence of gastrointestinal symptoms in children with autism: a population-based study. Pediatrics. 2009;124(2):680-6. https://doi. org/10.1542/peds.2008-2933

129. Coury DL, Ashwood P, Fasano A, Fuchs G, Geraghty M, Kaul A, et al. Gastrointestinal conditions in children with autism spectrum disorder: developing a research agenda. Pediatrics. 2012;130 Suppl 2:S160-8. https://doi.org/10.1542/peds.2012-0900N

130. Behl S, Mehta S, Pandey MK. Abnormal Levels of Metal Micronutrients and Autism Spectrum Disorder: A Perspective Review. Front Mol Neurosci. 2020;13:586209. https://doi.org/10.3389/ fnmol.2020.586209

131. Chvapil M. New aspects in the biological role of zinc: a stabilizer of macromolecules and biological membranes. Life Sci. 1973;13(8):1041-9. https://doi.org/10.1016/0024-3205(73)90372-X

132. Cho $\mathrm{CH}$, Ogle CW. The pharmacological differences and similarities between stress- and ethanol-induced gastric mucosal damage. Life Sciences. 1992;51(24):1833-42. https://doi. org/10.1016/0024-3205(92)90034-M

133. Reed S, Neuman H, Moscovich S, Glahn RP, Koren O, Tako E. Chronic Zinc Deficiency Alters Chick Gut Microbiota Composition and Function. Nutrients. 2015;7(12):9768-84. https://doi.org/10.3390/ nu7125497

134. Topping DL, Clifton PM. Short-chain fatty acids and human colonic function: roles of resistant starch and nonstarch polysaccharides. Physiol Rev. 2001;81(3):1031-64. https://doi.org/ 10.1152/physrev.2001.81.3.1031

135. Parada Venegas D, De la Fuente MK, Landskron G, Gonzalez MJ, Quera R, Dijkstra G, et al. Short Chain Fatty Acids (SCFAs)-Mediated Gut Epithelial and Immune Regulation and Its Relevance for Inflammatory Bowel Diseases. Front Immunol. 2019;10:277. https://doi.org/10.3389/fimmu. 2019.00277

136. den Besten G, van Eunen K, Groen AK, Venema K, Reijngoud DJ, Bakker BM. The role of short-chain fatty acids in the interplay between diet, gut microbiota, and host energy metabolism. J Lipid Res. 2013;54(9):2325-40. https://doi.org/10.1194/jlr.R036012

137. Gielda LM, DiRita VJ. Zinc competition among the intestinal microbiota. mBio. 2012;3(4): e00171-12. https://doi.org/10.1128/mBio.00171-12

138. McDevitt CA, Ogunniyi AD, Valkov E, Lawrence MC, Kobe B, McEwan AG, et al. A molecular mechanism for bacterial susceptibility to zinc. PLoS Pathog. 2011;7(11):e1002357. https://doi.org/10.1371/ journal.ppat. 1002357

139. Fraker PJ, King LE. Reprogramming of the immune system during zinc deficiency. Annu Rev Nutr. 2004;24:277-98. https://doi.org/10.1146/annurev.nutr.24.012003.132454

140. Meltzer A, Van de Water J. The Role of the Immune System in Autism Spectrum Disorder. Neuropsychopharmacology. 2017;42(1):284-98. https://doi.org/10.1038/npp.2016.158

141. Hughes HK, Mills Ko E, Rose D, Ashwood P. Immune Dysfunction and Autoimmunity as Pathological Mechanisms in Autism Spectrum Disorders. Front Cell Neurosci. 2018;12:405. https://doi. org/10.3389/fncel.2018.00405 
142. Gladysz D, Krzywdzinska A, Hozyasz KK. Immune Abnormalities in Autism Spectrum DisorderCould They Hold Promise for Causative Treatment? Mol Neurobiol. 2018;55(8):6387-435. https:// doi.org/10.1007/s12035-017-0822-x

143. Wrona D. Neural-immune interactions: an integrative view of the bidirectional relationship between the brain and immune systems. J Neuroimmunol. 2006;172(1-2):38-58. https://doi.org/10.1016/j. jneuroim.2005.10.017

144. Enstrom AM, Lit L, Onore CE, Gregg JP, Hansen RL, Pessah IN, et al. Altered gene expression and function of peripheral blood natural killer cells in children with autism. Brain Behav Immun. 2009;23(1):124-33. https://doi.org/10.1016/j.bbi.2008.08.001

145. Heuer L, Ashwood P, Schauer J, Goines P, Krakowiak P, Hertz-Picciotto I, et al. Reduced levels of immunoglobulin in children with autism correlates with behavioral symptoms. Autism Res. 2008;1(5):275-83. https://doi.org/10.1002/aur.42

146. Onore C, Careaga M, Ashwood P. The role of immune dysfunction in the pathophysiology of autism. Brain Behav Immun. 2012;26(3):383-92. https://doi.org/10.1016/j.bbi.2011.08.007

147. Gebhard RL, Karouani R, Prigge WF, McClain CJ. The effect of severe zinc deficiency on activity of intestinal disaccharidases and 3-hydroxy-3-methylglutaryl coenzyme A reductase in the rat. J Nutr. 1983;113(4):855-9. https://doi.org/10.1093/jn/113.4.855

148. Wapnir RA. Zinc deficiency, malnutrition and the gastrointestinal tract. J Nutr. 2000;130(5S Suppl): 1388S-92S. https://doi.org/10.1093/jn/130.5.1388S

149. Arons MH, Lee K, Thynne CJ, Kim SA, Schob C, Kindler S, et al. Shank3 Is Part of a Zinc-Sensitive Signaling System That Regulates Excitatory Synaptic Strength. J Neurosci. 2016;36(35):9124-34. https://doi.org/10.1523/JNEUROSCI.0116-16.2016

150. Grabrucker AM, Schmeisser MJ, Schoen M, Boeckers TM. Postsynaptic ProSAP/Shank scaffolds in the cross-hair of synaptopathies. Trends Cell Biol. 2011;21(10):594-603. https://doi.org/10.1016/j. tcb.2011.07.003

151. Rubenstein JL, Merzenich MM. Model of autism: increased ratio of excitation/inhibition in key neural systems. Genes Brain Behav. 2003;2(5):255-67. https://doi.org/10.1034/j.1601-183X.2003.00037.x

152. Pfaender S, Sauer AK, Hagmeyer S, Mangus K, Linta L, Liebau S, et al. Zinc deficiency and low enterocyte zinc transporter expression in human patients with autism related mutations in SHANK3. Sci Rep. 2017;7:45190. https://doi.org/10.1038/srep45190

153. Tao-Cheng JH, Toy D, Winters CA, Reese TS, Dosemeci A. Zinc Stabilizes Shank3 at the Postsynaptic Density of Hippocampal Synapses. PLoS One. 2016;11(5):e0153979. https://doi.org/10.1371/journal. pone.0153979

154. Grabrucker AM. A role for synaptic zinc in ProSAP/Shank PSD scaffold malformation in autism spectrum disorders. Dev Neurobiol. 2014;74(2):136-46. https://doi.org/10.1002/dneu.22089

155. Fourie C, Vyas Y, Lee K, Jung Y, Garner CC, Montgomery JM. Dietary Zinc Supplementation Prevents Autism Related Behaviors and Striatal Synaptic Dysfunction in Shank3 Exon 13-16 Mutant Mice. Front Cell Neurosci. 2018;12:374. https://doi.org/10.3389/fncel.2018.00374

156. Vyas Y, Lee K, Jung Y, Montgomery JM. Influence of maternal zinc supplementation on the development of autism-associated behavioural and synaptic deficits in offspring Shank3-knockout mice. Mol Brain. 2020;13(1):110. https://doi.org/10.1186/s13041-020-00650-0 
